\title{
Adopting Inflation Targeting in Pakistan: An Empirical
}

\author{
Analysis
}

\section{Nadia Saleem ${ }^{*}$}

\begin{abstract}
The objective of this paper is to assess the conditions for inflation targeting in Pakistan. The recent inflationary surge in Pakistan calls for rethinking monetary policy afresh. This paper argues the case for inflation targeting in Pakistan as a policy option to achieve price stability. The country experienced an inflation rate of just below 10 percent during 1970-2009, which makes it a potential candidate for inflation targeting. Applying the VAR technique to data for the same period, inflation is shown to be adaptive in nature, leading us to reject the accelerationist hypothesis. The Lucas critique holds as people are found to use forward-looking models in forming expectations about inflation. The paper also sheds some light on the State Bank of Pakistan's level of preparedness for the possibility of adopting inflation targeting, for which transparency and autonomy are prerequisites. The interest rate channel can play the role of a nominal anchor in the long run.
\end{abstract}

Keywords: Monetary policy, central bank, inflation targeting, Pakistan.

JEL Classification: C32, E31, E52.

\section{Introduction}

In recent years, the macroeconomic discourse has shifted from stability versus growth to stable growth because high inflation is a hindrance to sustained growth. The discussion then turned toward the effectiveness of monetary policy in controlling inflation. Money is not neutral, at least in the short to medium run, and it can generate inflation with lags; the central bank has no mechanism to exercise complete control over inflation. In the last two decades, countries have faced a contagion phenomenon and a worldwide liquidity crisis, raising the specter of another Great Depression. The experience points toward the miscalculations of monetary authorities in determining the role of money

* Associate Professor of Economics, FCC University, Lahore, Pakistan. 
and its impact on the real economy. The question is, how does a country that is otherwise doing well land itself in a financial crisis? The answer lies in people's self-fulfilling expectations and the fallacy of composition on the part of policymakers. Expectations about the future play an important role in investment and gross domestic product (GDP) growth. Emerging economies face increased import bills due to liberalized trade and fluctuations in commodity prices and shortages in food grains. Declining productivity, an acute shortage of energy, imperfect markets, and poor fiscal management present another challenge to the central bank agenda of price stability. ${ }^{1}$

Broadly speaking, central bankers have three choices available for achieving a stable inflation rate which can contribute to economic growth. First, the central bank can adopt discretionary monetary policy without any framework - a policy which simply fails to answer the questions that a central bank has to confront in light of an unstable money demand function. Alternatively, the central bank can control the exchange rate-a policy that relies heavily on the policies of central banks in importoriginating countries, besides requiring strong financial and economic conditions. Second, the central bank can opt for a rule-based monetary policy, which targets income instead of money or prices. Third, a central bank may choose to target inflation explicitly as "enemy number one"2 by making a transparent conditional forecast to make it accountable. A single choice or even a blend of all three is not considered the best policy for all countries, all time periods, or all types of environment. There is no such thing as a single, ideal monetary policy. It varies from country to country and with changing conditions. Each country needs a monetary policy that is robust, along with a conducive set of institutions, and commitment to fiscal responsibility for achieving the objective of price stability.

The idea behind inflation targeting (IT) goes back to the early Keynesian-monetarist debate on rules versus discretion. The central bank announces one long-term target but not its technical or mechanical operating instructions. It requires structural and judgmental models of

\footnotetext{
${ }^{1}$ Price stability refers to a consistent increase in price level such that people can form their expectations: "A situation in which households and businesses in making their saving and investment decisions can safely ignore the possibility of sustained, generalized price increases or decreases" (Greenspan, 1988).

${ }^{2}$ The political priority for price stability can be traced back to US President Ford's campaign for combating inflation: "Whip Inflation Now" (WIN). In an address to Congress (Ford, 1974), he declared inflation enemy number one. After this, a controversy started with a counter movement, "Need Immediate Money" (NIM).
} 
the economy, which help attain the inflation target. The central bank "looks at every other thing" but is focused on inflation (Svensson, 2000). In the words of Bernanke et al. (1999): "IT is constrained discretion which keeps the economic ship in the desired area in the long run, while permitting central bank to respond in the short run."

There are two important decisions involved in IT. The first is to choose an optimal horizon and the second is the choice of anchor. The central bank announces a target and then focuses on the expected inflation rate because of lags in the monetary transmission mechanism. In the case of open economies, an effective monetary policy works through the output gap channel instead of the exchange rate channel. Once a shock is generated, inflation deviates from the target, the central bank recognizes that inflation affects the real variables with a lag, and can use an instrument before the shock is fully absorbed by the economy to minimize loss of output. This is the look-at-everything approach mentioned earlier. The other approach, attributed to Batini and Haldane (1999) and McCallum and Nelson (1999) requires a policy rule for controlling inflation. ${ }^{3}$

This paper is concerned primarily with two aspects: (i) to examine the preconditions of IT as a policy choice in developing economies, and (ii) to assess the level of preparedness for the adoption of IT as a policy framework in Pakistan. Section 2 outlines and analyses the preconditions for IT and its success and failure in developing, transition, and developed economies. It accounts for the elements of success of IT in developing economies on the basis of empirical evidence and discusses issues related to the adoption of this policy in Pakistan. Informed by these conclusions, Section 3 outlines a VAR model applicable to conditions in Pakistan and presents the sources of data used. Section 4 gives detailed empirical results and compares them with earlier studies. The last section summarizes our findings and proposes a future course of action for the State Bank of Pakistan (SBP) to adopt IT.

\section{Preconditions and Performance}

IT as a monetary policy regime emerged at the time when the East Asian crisis threatened the world's financial stability. Ever since, the world has been divided between inflation targeters and nontargeters-a division reminiscent of the world when paper money was introduced, with arguments as to whether or not gold and silver standards could

${ }^{3} R T=$ Constant $+\phi\left(\pi_{t+1}-\pi_{t}\right)$, where Rt is the nominal interest rate, $R T>1, \pi_{t+1}$ is the forecasted inflation rate and $\pi_{t}$ is the targeted inflation. 
work simultaneously. This section looks at the set of preconditions that has developed under IT regimes and the performance of these regimes compared to non-IT regimes. We focus specially on developing countries.

\subsection{Preconditions}

As a regime, the following set of conditions must be fulfilled before IT is introduced into an economy: (i) a strong commitment to price stability, (ii) a numerical target for inflation, (iii) a time horizon for achieving that target, and (iv) an autonomous, transparent, and accountable central bank to hold these factors together. The first order of business for the central bank is to opt to control price, not money or income, implying a reversal of causality from prices to money. Second, it has to decide what the desired level of inflation should be. The importance of price stability must always be paramount; higher inflation should invariably be a cause for serious concern for the central bank. IT thus requires a conservative central bank with a credible monetary policy.

IT varies from a strict, fully-fledged regime with a single anchor to a flexible regime with a floating exchange rate and an inflation target. If the commitment to price stability is high and it is the objective of monetary policy, then the central bank will select strict IT. High commitment translates into a shorter time horizon and the central bank stands ready to take action quickly; it will increase the sacrifice ratio and unemployment loss. The time horizon varies from 12 to 60 months.

With a view to announcing the target, IT needs a forward-looking model to forecast inflation. A nominal anchor must be chosen, which requires greater transparency and to which people can respond. Once the central bank announces IT as a policy regime, it has also to announce the target inflation rate and the nominal anchor that will pin down private expectations. This may be any instrument that is directly and monotonically related to the inflation rate. The choice of nominal anchor is important because it resolves the problems of time inconsistency and the disciplining of monetary policy (Mishkin, 1998). Policymakers may choose the interest rate, money supply, or exchange rate as an anchor. In most countries adopting IT, the nominal interest rate is considered an operational instrument. The short-run nominal interest rate is recommended as a targeting instrument for its negligible impact on the long-run real interest rate and if inflation deviates from the target, the nominal interest rate will be affected without adversely impacting output. Monetary policy is concerned not with the current level of output, but 
with the future utilization of resources. Stable prices can contribute to achieving this objective (Gaiduch and Hunt, 2000).

IT requires the regular transmission of information to the public and private sectors about the affairs of the central bank. This transmission involves information related to the prediction of inflation, the path of the instrument, and a policy statement. This type of public statement limits discretion. It also demands close contact between monetary and fiscal policy without sacrificing the independence of the central bank. The next step is to determine how best to provide this information to the public. Various methods have been used to bridge the information gap between the central bank's decisions and the household and business sectors. The central bank can use an information flow chart, making a public announcement concerning inflation, and publishing the minutes of meetings, etc. This mechanism helps form expectations. In this way, the central bank helps people adopt a certain type of behavior. Most inflation targeters use fan charts to transmit the target and the path of the instrument, while New Zealand, Canada, Israel, Australia, Mexico, and Poland rely on making the central bank's minutes public. These public announcements make the central bank more answerable to the public. It is forced to adopt more transparent policies and account for instances where it fails to achieve the target. If the interest rate increases, private businesses know why and can learn about the future inflation rate. IT thus makes the central bank more objective in its actions; it brings about systematic changes in the policy rate.

The operational statement of IT can vary from strict to flexible and, on the basis of the target inflation rate, countries can be subdivided into maintainers, convergers, squeezers, and reversers. Maintainers are those who successfully maintain the stationary inflation rate at less than 5 percent. Convergers are those on the way to achieving a stationary inflation rate and their inflation rate is less than 10 percent. Squeezers are countries that have started to bring their inflation rate down to singledigit figures, and reversers are those who have achieved a zero inflation rate (Truman, 2005).

\subsection{Successes and Failures}

In the past two decades, 26 countries have embraced IT as a policy regime and many others are getting ready to adopt it. New Zealand (1990), the United Kingdom (1993), Australia (1994), Canada (1994), and Finland (1994) were the first to formally adopt IT. It was seen as a regime suitable for industrially developed countries. Evolved during financial 
crises, the policy was considered the answer to the unusual shocks that monetary policy has to confront in the form of output variability and exchange rate fluctuations. However, inflation targeters also include emerging and transitional economies such as Brazil, Mexico, Colombia, Peru, the Republic of Korea, Thailand, Philippines, the Czech Republic, Hungary, Poland, and South Africa. The latest additions are Slovakia, Indonesia, Romania, Turkey, and Ghana. The variety of countries that have adopted IT shows that it is becoming an accepted policy choice in all kinds of economies, including emerging and developing economies.

Ball et al. (2003) find no evidence as to whether IT improves the economic performance of targeters compared to nontargeters. This is not because IT is unable to achieve macroeconomic stability along with price stability, but because both groups are using the same type of interest rate policy. Further, there is no evidence that if IT fails to deliver, it might harm a country's macroeconomic conditions. Further still, the authors conclude that IT might be desirable for political rather than economic reasons.

\section{Figure-1: Average Annual Inflation Rate and Standard Deviation}

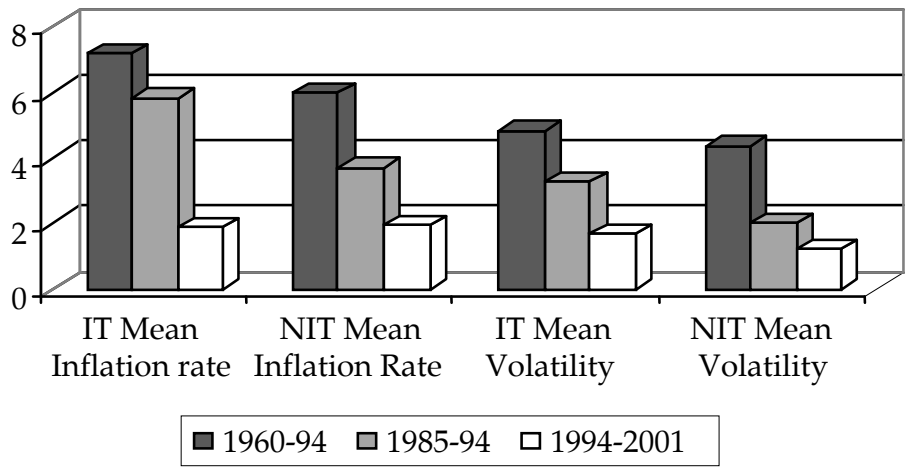

Source: Ball et al. (2003).

Figure-1 shows that noninflation targeters' (NITs) inflation rate (5.98 percent) was lower than that of inflation targeters (7.17 percent) during the period 1960-1994. NITs performed better than inflation targeters in controlling their inflation rate. Thus, it is the high inflation rate that leads inflation targeters to adopt IT. After adopting IT as a rule (1994-2001), inflation targeters were able to bring inflation down from 5.84 to 1.88 percent. This is not only a measure of success with respect to their previous record of inflation, but also with respect to NITs where the mean inflation rate was 1.95 percent during 1994-2001. IT not only enabled these countries to control inflation more successfully but also 
reduced volatility of inflation which, measured by the standard deviation, is less in targeters than in NITs.

Figure-2: Growth Rate and Inflation Rate

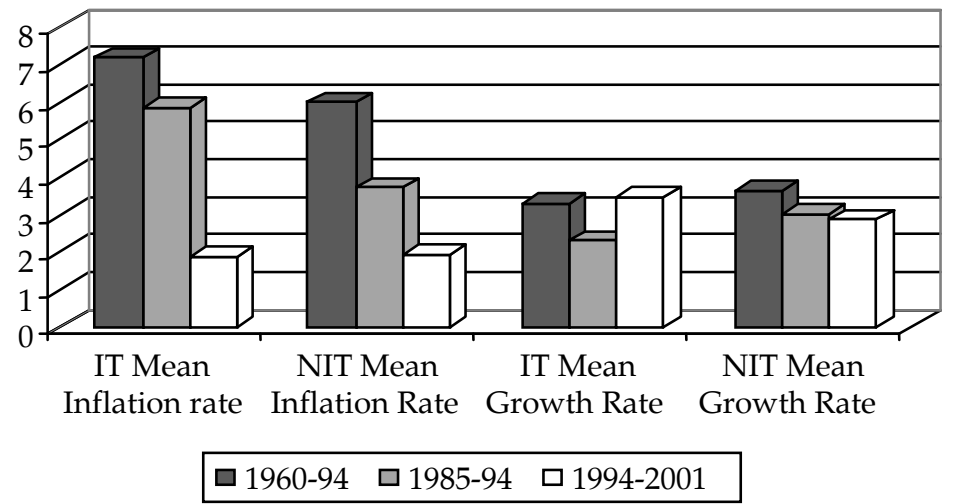

Source: Ball et al. (2003).

Figure-2 shows that targeters initially have higher inflation rates than NITs. But inflation affects growth as countries experiencing high inflation tend to have lower growth rates. Although the inflation rate remains more or less the same for targeters and NITs after the central bank has adopted IT as a policy regime, the growth rate for inflation targeters accelerates. It seems that IT does not have any adverse impact on the growth rate. We can also conclude that adopting IT adoption reduces variability in the inflation rate and can facilitate growth.

\subsection{IT in Developing Economies}

Developing economies suffer from weak financial institutions, a lack of will to implement policies, and excess aggregate demand, all of which make it difficult to avoid inflationary pressures. The demand for money is not a stable function so the short-term interest rate can be considered an option to monitor the demand for liquidity.

The success story of Chile in controlling inflation started a debate among developing economies, as its experience indicated another path available to central banks. Most analysts maintain that Chile's success in adopting IT was attributable to the absence of a fiscal deficit. Further, the strict regulation and supervision of the financial system and substantial tightening of targets are also cited as reasons for success. The second example is that of Israel, which won credibility by preemptive actions 
taken by the monetary authorities whenever there was a deviation from the target.

According to Masson et al. (1997), a program of fiscal consolidation, tight monetary policy, and institutional reform will be more effective in reducing the inflation rate in countries where it has been 30-40 percent annually and short lags exist in the implementation of monetary policy. Many economists recognize that developing economies have high seigniorage, which makes them unsuitable candidates for adopting IT. High seigniorage does not always lead to high inflation. The first necessary condition is political will and determination, while economic conditions come second. Boughrara (2004) concludes that a weak financial structure, fragile banking system, and incomplete knowledge of the monetary transmission mechanism-rather than fiscal dominance-are the main obstacles to adopting IT. Necessary and sufficient conditions apart, Angeriz and Arestis (2005) notice that administered prices and a high exchange rate pass-through regime play a crucial role. These two factors require effective coordination between fiscal and monetary policy with high vigilance. Arguably the greatest problem with IT, according to Svensson (1999), is the central banks' imperfect control of inflation due to the lags in and uncertainty about the transmission mechanism. Further, lack of accountability and transparency can reduce the potential benefits of IT.

The choice of IT is also influenced by "economic performance, conditions, structures and institutions" (Truman, 2005). A rapidly growing country satisfied with its performance is less likely to opt for IT as a monetary policy framework. Hu (2003) supports this view and explains that interest rates are negatively related and exchange rate pressures are positively related to the choice of switching to IT. Higher variability in growth, inflation, and interest rate sets the stage for IT in developing economies.

Kadioglu et al. (2000) concludes that many developing countries fail to satisfy the preconditions for IT and do not have powerful models to enable them to make successful inflation forecasts. Gottschalk and Moore (2001) show that exchange rates were effective in the case of Poland with respect to output and prices, and the direct linkages between interest rate and inflation did not appear to be very strong.

More recently, Ghana has formally adopted IT. It is only the second country after South Africa to announce a target of 5 percent for 
inflation and the interest rate as the major anchor. Since adopting IT, interest rates have increased from 12.5 percent to 14.3 percent. Although a fiscal responsibility act had already been promulgated, inflation increased from the targeted 5 percent to 13.2 percent. This high rate of inflation was due to supply shocks and in this scenario, increasing the interest rate would be a drastic step. Severe supply shocks (rising oil and food prices) and falling exchange rates were real constraints on the success of IT in Ghana (Mckinley, 2007).

Table 1 explains how IT is adopted in transitional and developing economies. Chile, the Czech Republic, and Brazil suffered high to very high inflation rates at the time of adopting IT, while the Republic of Korea faced an economic downturn. Moreover, a high fiscal deficit prevailed in all these countries. They used monetary aggregates, or M2 growth, as a nominal anchor, effective and strong communication mechanisms, and the short- to long-term horizon for targeting inflation, and IT resulted in low inflation. These economies are transitional in nature, even if they are stable market economies because they are growing and working at a suboptimal level. To predict the future path of inflation and expectations in such countries is difficult, if not impossible. These are also those countries that have a long history of inflation and are even tolerant of a certain level of high inflation because it contributes to growth. Further, commitment and institutional support is often a problem in controlling inflation. Countries that have faced problems in implementing IT are Turkey and Ghana. They have opted for exchange rate management along with monetary aggregates, but there has been poor coordination with fiscal policy and a weak communication system.

Based on Table-1, we can conclude that strong commitment and effective communication, which helps people believe that the central bank will control inflation, is a real factor of success. The central bank should be capable of developing a forward-looking model of inflation based on an effective channel. IT has been successful in those countries where the central bank adopted a flexible exchange rate rather than floating or fixed exchange rate regimes. 
Table-1 Assessing IT in Developing and Emerging Economies

\begin{tabular}{|c|c|c|c|c|c|c|c|}
\hline Country & Monetary Policy Regime & Problem & Communication Strategy & Autonomy & Fiscal Situation & $\begin{array}{l}\text { Impact on } \\
\text { Inflation }\end{array}$ & Horizon \\
\hline Chile & $\begin{array}{l}\text { Pegged and monetary } \\
\text { aggregates }\end{array}$ & $\begin{array}{l}\text { High inflation } \\
\text { with fear of } \\
\text { floating }\end{array}$ & $\begin{array}{l}\text { Effective and strong } \\
\text { monthly inflation } \\
\text { report }\end{array}$ & Full autonomy & $\begin{array}{l}\text { High fiscal } \\
\text { deficit }\end{array}$ & Low inflation & $\begin{array}{l}\text { Long term } \\
\text { horizon }\end{array}$ \\
\hline $\begin{array}{l}\text { Czech } \\
\text { Republic }\end{array}$ & $\begin{array}{l}\text { Pegged and monetary } \\
\text { aggregates }\end{array}$ & High inflation & $\begin{array}{l}\text { Problems in } \\
\text { communication and } \\
\text { reaction }\end{array}$ & No sovereignty & $\begin{array}{l}\text { High fiscal } \\
\text { deficit }\end{array}$ & Low inflation & $\begin{array}{l}\text { Short term } \\
\text { horizon }\end{array}$ \\
\hline Brazil & $\begin{array}{l}\text { Monetary } \\
\text { aggregates and pegged } \\
\text { exchange rate }\end{array}$ & $\begin{array}{l}\text { Very high } \\
\text { inflation rate }\end{array}$ & $\begin{array}{l}\text { Quarterly report on } \\
\text { inflation and minutes } \\
\text { of meeting }\end{array}$ & High autonomy & $\begin{array}{l}\text { High fiscal } \\
\text { deficit }\end{array}$ & $\begin{array}{l}\text { Low } \\
\text { inflation }\end{array}$ & $\begin{array}{l}\text { Short term } \\
\text { horizon }\end{array}$ \\
\hline Korea & $\begin{array}{l}\text { Monetary target to an } \\
\text { M2 } \\
\text { Growth rate }\end{array}$ & $\begin{array}{l}\text { Economic } \\
\text { down- turn }\end{array}$ & $\begin{array}{l}\text { Effective } \\
\text { communication with } \\
\text { the private sector }\end{array}$ & $\begin{array}{l}\text { Autonomy in } \\
\text { implementing } \\
\text { monetary policy }\end{array}$ & $\begin{array}{l}\text { No fiscal } \\
\text { deficit }\end{array}$ & $\begin{array}{l}\text { Lower } \\
\text { inflation rate }\end{array}$ & $\begin{array}{l}\text { Longer } \\
\text { horizon }\end{array}$ \\
\hline Turkey & $\begin{array}{l}\text { Nominal floating } \\
\text { Exchange rate }\end{array}$ & High inflation & $\begin{array}{l}\text { Weak communication } \\
\text { quarterly inflation } \\
\text { reports }\end{array}$ & $\begin{array}{l}\text { Coordination } \\
\text { with fiscal } \\
\text { policy }\end{array}$ & $\begin{array}{l}\text { High fiscal } \\
\text { deficit }\end{array}$ & $\begin{array}{l}\text { Higher } \\
\text { inflation }\end{array}$ & $\begin{array}{l}\text { Longer } \\
\text { horizon }\end{array}$ \\
\hline Ghana & $\begin{array}{l}\text { Exchange-rate } \\
\text { management and } \\
\text { monetary aggregates }\end{array}$ & $\begin{array}{l}\text { Very high } \\
\text { inflation rate }\end{array}$ & $\begin{array}{l}\text { Weak communication } \\
\text { annual inflation } \\
\text { reports }\end{array}$ & $\begin{array}{l}\text { Coordination } \\
\text { with fiscal } \\
\text { policy }\end{array}$ & $\begin{array}{l}\text { High fiscal } \\
\text { deficit }\end{array}$ & $\begin{array}{l}\text { Higher } \\
\text { inflation }\end{array}$ & $\begin{array}{l}\text { Longer } \\
\text { horizon }\end{array}$ \\
\hline
\end{tabular}

Sources: International Monetary Fund (2007a).

Data for Chile is taken from Hebbel and Tapia (2003).

Data for the Czech Republic is taken from Kotlán and Navrátil (2003); Czech (2001).

Data for Turkey is taken from Airaudo (2004), Ozatay (2004), Fkadioğlu, Ozdemir and Yilmaz (2000).

Data for Korea is taken from Hanson and Nam (2005), Kim and Park (2006), Hoffmaister (2001).

Data for Brazil is taken from the Research Department of the Central Bank, Brazil (2000).

Data for Ghana is taken from the Central Bank of Ghana, McKinley (2008) and Opoku-Afari (2008). 
A number of points emerge in the case of developing economies. First, inflation is arguably an acceptable malaise in developing economies because of the high priority given to capital accumulation and the infant industry argument. Inflation generates capital gains and controlled interest rates boost investment incentives, which contribute to GDP growth. For this reason, developing countries generally emphasize increasing exports and controlling imports. Central banks try to manage the exchange rates and intervene in exchange rate markets. Second, in the absence of comprehensive analytical grounds for estimating inflation and output loss functions, the probability of the success of IT remains limited. Third, either central banks in developing economies believe in disequilibria in the money market as a cause of inflation or they consider the budget deficit as a reason for inflation. They might also believe in imported inflation and the exchange rate as a reason for wages to rise and trigger cost-push inflation as the first layer of inflation in the economy. The main argument in developing countries is that the interest rate has to be kept low for investment and inflation has to be tolerated in the interest of growth. There is less appreciation of the likelihood of uncertainty associated with inflation damaging expectations and hence affecting growth adversely.

\subsection{Conditions for an IT Rule in Pakistan}

The financial crises of the 1990s showed the need to adopt more market-oriented policies. An important element in the process of liberalization was the first steps taken in 1993 toward an autonomous State Bank of Pakistan (SBP), the central bank of the country. In 2001/02, the SBP adopted a free-floating exchange rate, reflecting its willingness to put its house in order by adopting a market-based monetary policy, a liberalized exchange rate regime, and an adjustment in T-bills' interest rate as an anchor for investment-friendly environment. It was against this backdrop that the debate on whether or not IT could be successfully implemented in Pakistan started. Gleaning from the experience of the IT countries outlined earlier, it can be said that adopting IT requires the existence of high inflation, sound financial markets, low fiscal dominance, an autonomous central bank that can independently choose a monetary policy stance, strong commitment and an effective and open channel of information with the public helping it form expectations about the future, and a nominal anchor that has a strong relationship with inflation. We now contextualize these conditions for Pakistan. 


\subsubsection{Inflation Rate}

In Pakistan, the average annual inflation rate was 9.06 percent during 1970-2009, with a standard deviation of 5.61.4 This is moderately high and volatile in nature. Inflation volatility and the associated uncertainty may generate a negative shock to output. Recently, the SBP took a tight monetary policy stance. The business sector raised a great hue and cry against higher interest rates, but it is not doing anything about the less concerned with the issue of productivity, which is important for increasing output when the economy is working below its potential level.

\subsubsection{Nominal Anchor}

The SBP has been using growth in broad money as an anchor to control inflation. There is discretion with a sense of safe limits, but this is not always the case in practice. Monetization of public debt is the main reason for monetary expansion in Pakistan. As a result, the SBP has lost control over broad money as an instrument to influence prices. M2 and inflation has two-way causation only with one lag but this bilateral causation fails with two lags. In the short run, M2 is not considered a reliable indicator of changes in monetary conditions and measurement of M2 as an indicator of demand for money is unstable. The recent liquidity crunch has made the situation worse.

The other variable that could lend itself as an anchor and is used in other developing economies is the exchange rate. Pakistan has already adopted a flexible exchange rate, which is in effect a dirty float. Evidence shows that there is very low exchange rate pass-through to inflation in the case of Pakistan. This is also due to the fact that net exports are not significant. Our results suggest that, whenever inflation increases, it affects the interest rate, and this results in the depreciation of the exchange rate. Pakistan has adopted a floating exchange rate regime but, as already noted, it intervenes whenever there is a crisis.

The third variable that could perform as a nominal anchor is the short-run interest rate. There exists a two-way causation between inflation and the call money rate in Pakistan. The anchor should have a long-run relationship with inflation and must be stable. In Pakistan, interest rates have been kept low most of the time and inflation has been high, which has had a negative effect on output. As the interest rate has a positive and significant relationship with the inflation rate, it can be used as an anchor. If inflation occurs in the economy, the interest rate will move to adjust. The

\footnotetext{
${ }^{4}$ For details see Saleem (2008).
} 
real interest rate remains rigid, which shows that, due to the implications for debt and growth, the SBP has always been reluctant to allow changes to the real interest rate. The movement in the interest rate depends on the conditions prevailing in financial markets, not on policy. In Pakistan the M2/GDP ratio was almost constant throughout the 1990s and during 200005, the M2/GDP ratio increased drastically but was still low compared to other developing economies. Money supply increase shows financial deepening. Further, at an inflation rate of just under 10 percent, the interest rate is sensitive to inflation monitoring.

\subsubsection{Conditions in the Financial Markets}

Pakistan's financial markets are underdeveloped and comprise capital, money, and forex markets in the economy. The capital market consists of three stock markets in Karachi, Lahore, and Islamabad. It is highly volatile due to the narrow investor base. The money market comprises the banking sector, which had a total of 41 banks with 7,746 branches in June 2007. On average, one branch serves around 200,000 persons. Only 15 percent of the population has bank accounts. Most bank branches cluster together in urban areas. According to a recent study, 40 percent of the population has no access to financial services, formal or informal (Nenova et al., 2009).

The banking system has enjoyed rigid 'repo rates' and a controlled interest rate. Restructuring of the banking sector and overall financial sector reform started in the early 1990s under the umbrella of the International Monetary Fund (IMF) and World Bank. Two important objectives of the reforms were to reduce financial intermediation costs and government reliance on bank borrowing. Progress has been slow because of the increasing trend of seigniorage, the inflation rate, and interest rate spreads.

IT demands a vibrant financial sector, which can adjust itself according to market needs. Fragile, less integrated financial markets are the real hindrance in adopting IT. Markets give signals to individuals and rational economic agents respond to incentives. Distortions in markets impede these signals and create rigidities. Efforts to remove rigidities from the country's financial markets have met with partial success. The answer to how markets grow does not lie in a half-hearted reform agenda.

\subsubsection{Autonomy of the SBP}

The SBP has suffered from government influence like many other central banks, and it is not fully independent in the making of monetary 
policy. Although a certain degree of coordination is recommended between monetary and fiscal policy for developing economies, a central bank cannot sacrifice the objective of price stability over the government's proclivity towards short-run inflationary growth. Autonomy was granted to the SBP in 1993, but the intrusive ministry of finance continues to effectively dilute it. The weak stance of monetary policy and lukewarm concern for controlling inflation reflect weak autonomy.

Several measures have been taken in the name of economic stability. The Fiscal Responsibility and Debt Limitation Act 2004 was passed with the objective of reducing the fiscal deficit and debt burden. However, it does not place any limit on the federal government's borrowing from the SBP. ${ }^{5}$ A floating exchange rate regime was adopted for increasing export competitiveness and decreasing dependence on external inflows. In practice, however, the SBP has, more often than not, preferred short-run growth over long-run price stability. The government has a growth agenda for which the SBP invariably sacrifices price stability. Monetary policy is tightened only when the government fails to raise financing from foreign sources in the form of remittances and debt, forcing an arrangement with the IMF. The SBP has kept the interest rate low and financed the government to meet short-run obligations. Which has had adverse implications for the investment climate and for the availability of credit to the private sector. Furthermore, it has been slow in nurturing capital markets which function efficiently so that the government can rely on it to fulfill its financing needs.

The autonomy of a central bank can be measured by fiscal dominance. We measured seigniorage for Pakistan as a proxy for fiscal dominance, which turns out to be very high. With a maximum value of 26.89 percent and minimum value of 0.75 percent, its average lies at 7.32 percent. At 5.62 per cent during 1970-2005, the standard deviation is also very high. The absence of fiscal dominance is a prerequisite for pursuing IT. High seigniorage also suggests the existence of a fragile financial market, limiting the options available for nonbank borrowing.

\subsubsection{Volatility of Growth and Inflation}

Inflation volatility is a source of uncertainty in economic growth. Further, inflation volatility is significantly and positively related to the level of inflation. Put together, these conclusions support the widely held

\footnotetext{
${ }^{5}$ Recently, the National Assembly passed a bill to amend the State Bank Act to reduce fiscal dominance and place limits on bank borrowing; it awaits the approval of the Senate.
} 
belief that inflation uncertainty adversely affects economic growth. This type of relationship between a volatile inflation rate and growth creates concern in the central bank and it makes the case for stabilization. In the case of Pakistan, inflation is volatile and our findings have shown that growth is inflationary. The SBP has preferred the growth objective to price stability. Inflation has never been high on the SBP's priority list, but this policy has failed to minimize the output gap.

The SBP has started using interest rate adjustment but it also has to finance the fiscal deficit. This lowers its commitment to controlling inflation and transparency in its operations. Its communication with the public is weak and there is no forward-looking behavioral model for the inflation rate and these are real obstacles to the success of IT in Pakistan. Again, the SBP has not played an active role in facilitating the public in forming expectations. Dealing with these issues may seem a daunting task, but by giving priority to the public and demonstrating a commitment to inflation control, reform through market signals can be started to put the economy on a sustainable path to stable growth.

\section{The Model and its Data}

We take Soderstorm's (1999) model and modify it on the basis of the literature on open economies and the response of the central bank to controlling inflation. Soderstorm criticized the Sevensson (1998) model for failing to incorporate an explicit interest rate equation and showed that this results in a more aggressive policy prescription. Our model introduces an explicit interest rate equation. Investment is crucial to growth in a developing economy. The central bank cannot afford to implement an aggressive policy to control inflation because of the inverse relationship between the interest rate and investment.

Formulated in this way, our model gives us the following relationship between the output gap, inflation rate, and interest rate.

$$
y_{t+1}=\alpha(L) y_{t}+\beta(L)\left(i_{t}-\pi_{t}\right)+\varepsilon_{t+1}
$$

This equation measures the aggregate demand type relationship between the output gap and its lag terms, where $y_{t}$ is the gap between actual and potential GDP. A potential output series is generated using the Hodrick-Prescott filter to smooth the trend. It is widely used to obtain a smooth estimate of the long-term trend component of a series. Thus the output-inflation gap is measured on the basis of percentage deviation 
from trend, the deviation between the interest rate and inflation rate. The term $\left(i_{t}-\pi_{t}\right)$ explains inflationary expectations and the interest rate path in the economy. This type of path helps in forming expectations. As we are following the rational expectations hypothesis, these expectations are measured in the form of an average relationship.

The inflation rate is measured by an aggregate supply type of equation:

$$
\pi_{t+1}=\delta(L) \pi_{t}+\gamma(L) y_{t}+\mu_{t+1}
$$

It relates the lead inflation rate to its current and lagged inflation rate, and output gap. It is assumed to follow an accelerationist type Philips curve relationship (Svensson, 1998).

This is a modified version of the parameter $\delta$ because it can assume any value different from 1 and is stochastic but not time varying. We were unable to use the time varying coefficient technique because of data limitations. In this paper, we have used annual data for the period 1970-2009.

A VAR representation explains that the central bank has to set the interest rate while adjusting output and inflation in the economy. This model tests whether the central bank's behavior is moderate or aggressive in controlling inflation.

$$
\begin{aligned}
& y_{t+1}=\sum_{s=1}^{L} A_{s}^{y} y_{t-s}+\sum_{s=1}^{L} B_{s}^{y} \pi_{t-s}+\sum_{s=1}^{L} C_{s}^{y} i_{t-s}+\varepsilon_{t}^{y} \\
& \pi_{t+1}=\sum_{s=1}^{L} A_{s}^{\pi} y_{t-s}+\sum_{s=1}^{L} B_{s}^{\pi} \pi_{t-s}+\sum_{s=1}^{L} C_{s}^{\pi} i_{t-s}+\varepsilon_{t}^{\pi} \\
& i_{t+1}=\sum_{s=1}^{L} A_{s}^{i} y_{t-s}+\sum_{s=1}^{L} B_{s}^{i} \pi_{t-s}+\sum_{s=1}^{L} C_{s}^{i} i_{t-s}+\varepsilon_{t}^{i}
\end{aligned}
$$

$\pi_{t}$ is the annual CPI inflation rate, $i_{t}$ is the call money rate, and $y_{t}$ is the output gap. This model assumes that the central bank is not only responsible for price stability but also for maintaining financial stability and a congenial macroeconomic environment. It further assumes that shocks and changes in monetary and fiscal policy have no impact. In this way, the modified model deals with the supply side and demand side 
equations in the open economy and explicitly recognizes interest rate and exchange rate adjustments in the open economy. An unrestricted VAR is used to estimate the model and forecast the future inflation rate (Soderstorm, 1999).

Our sources for the annual data series for the period 1970-2008 include World Development Indicators (World Bank, 2005), International Financial Statistics (IMF, 2007b), various issues of the Pakistan Economic Survey, and the website of the Federal Bureau of Statistics.

\section{Empirical Results}

\section{Inflation Rate in a Closed Economy}

Equation 1 explains the aggregate demand relationship in the economy for the study period. It relates the output gap to its own lag and lead relationships and the difference between the inflation rate and shortrun interest rate, which is the call money rate in Pakistan. The results show that

$$
\begin{aligned}
& \log y_{t+1}=1.48+1.85 \log y_{t}-1.14 \log y_{t-1}-0.17\left(\pi^{\exp }-i^{\exp }\right)+\eta_{t} \\
& \begin{array}{lllll}
\text { S.E. } & (2.04) & (0.62) & (0.44) & (0.26)
\end{array} \\
& \mathrm{t} \text { - ratio } \quad(0.725) \quad(2.98) \quad(-2.59) \quad(0.65) \\
& \mathrm{R}^{2}=0.86 \quad \text { D.W }=1.95 \quad \text { S.E. }=3.13
\end{aligned}
$$

We use the OLS method for estimation. This equation confirms that in determining aggregate demand, the rational expectations hypothesis holds with particular force. We impose restrictions on the coefficients of the output gap and reject the null hypothesis to conclude that people show forward-looking behavior in forming their expectations.

Estimates of the aggregate supply equation show that the future rate of inflation depends on the lag series of the inflation rate, confirming that inflation is adaptive. All the coefficients are less than 1 so we reject the accelerationist hypothesis and confirm that no inflation-unemployment trade off existed in Pakistan during the study period. We can suggest the existence of a vertical type of Philips curve in Pakistan whereby individuals can synthesize information to offset policy effects. Inflation thus does not generate unemployment in Pakistan. These results are in line with the original empirical study of Rudebusch and Sevensson (1998). 


$$
\begin{array}{ccccc}
\log \pi_{t+1}= & 0.55 \log \pi_{t}-0.013 \log y_{t}+0.38 i_{t-1}-0.077 \log x r_{t-1}+\varepsilon_{t} \\
\text { S.E. } & (0.20) & (0.077) & (0.27) & (0.16) \\
t-\text { ratio } & (2.75) & (-0.168) & (1.41) & (0.48) \\
R^{2}=0.57 & \text { D.W }=2.01 & \text { S.E. }=0.369
\end{array}
$$

We impose linear restrictions to check that the sum of all autoregressive terms is equal to 1 . The results of the Wald test show that the null hypothesis that inflation is adaptive in nature for the period 19702009 is not rejected. It also means that the SBP is using a backwardlooking model rather than a forward-looking path to determine the inflation rate in the economy. We check the results for the stability test by examining the CUSUM and CUSUM square test, which confirms that the model is stable. Our model's results are comparable with other empirical findings of Soderstorm (1999) and Rudebusch and Sevensson (1998), which enhances the plausibility of our estimates. These results support the original empirical study of Rudebusch and Sevensson (1998).

\subsection{VAR Results}

To estimate the stability of the variables, we estimate an unrestricted vector autoregressive (VAR) model. This enables us to measure the sensitivity of the policy instrument, i.e., of the interest rate to the output gap and its impact on controlling inflation. Tests such as the augmented Dickey-Fuller (ADF) were applied to data on the inflation rate measured on the basis of the CPI $\left(\pi_{t}\right)$, the lending rate measured on the basis of the average call money rate $\left(i_{t}\right)$, and the output gap $\left(y_{t}\right)$. The maximum lag length is 1 , determined on the basis of the Akiake information criterion. Each column in the VAR summary table represents the equation in the system. 
Table-2: VAR Results 1970-2009

\begin{tabular}{lccc}
\hline \multicolumn{1}{c}{$\pi_{\mathrm{t}}$} & \multicolumn{1}{c}{$Y_{t}$} & \multicolumn{1}{c}{$i_{t}$} \\
\hline$\pi_{\mathrm{t}-1}$ & 0.734 & -0.001 & 0.142 \\
$\mathrm{t}-$ ratios & {$[4.93]^{*}$} & {$[-0.17]$} & {$[3.12]^{*}$} \\
$\mathrm{Y}_{\mathrm{t}-1}$ & -0.404 & 0.98 & -0.119 \\
$\mathrm{t}-$ ratios & {$[-0.45]$} & {$[23.2]^{*}$} & {$[-0.43]$} \\
$\mathrm{i}_{\mathrm{t}-1}$ & -0.676 & 0.007 & 0.631 \\
$\mathrm{t}-$ ratios & {$[-1.98]^{* *}$} & {$[0.45]$} & {$[6.05]^{*}$} \\
Intercept & 10.33 & 0.085 & 2.41 \\
$\mathrm{t}-$ ratios & {$[1.695]$} & {$[0.296]$} & {$[1.292]$} \\
Adj. -squared & 0.375 & 0.94 & 0.65 \\
Akaike Information & & & \\
Criterion & 5.93 & -0.196 & 3.56 \\
Schwarz Information & & & \\
Criterion & 6.1 & -0.02 & 3.73 \\
F-statistic & 8.39 & 192.7 & 23.99 \\
Log likelihood & -108.58 & 7.72 & -63.56 \\
\hline
\end{tabular}

* Indicates significance at 1 percent level ${ }^{* *}$ Indicates significance at 5 percent level

The results of VAR inflation equation (4) $\left(\pi_{\mathrm{t}}\right)$ explain the relationship between inflation and its lag value, output gap, and shortrun interest rate. It shows that the inflation rate is determined by the previous value of inflation and that it is significant. The output gap is negatively related to the inflation rate but is insignificant. The interest rate is negatively related and significant. We can conclude that the interest rate does affect the inflation rate.

Equation 3 measures the relationship between the output gap and the lag value of inflation rate and call money rate. The output gap is negatively related to the lagged value of the inflation rate, and positively related to the lagged value of the output gap and interest rate. However neither the inflation rate nor the interest rate is significant in explaining the output gap in the economy.

Equation 5 explains the interest rate and its responsiveness to inflation rate. The lagged value of the inflation rate affects the interest rate. This indicates the interest sensitivity of inflation. 


\section{Conclusions and Policy Implications}

On the basis of empirical evidence, we can conclude that inflation is monetary and that the central bank can control inflation in Pakistan using the interest rate as a nominal anchor because there exists a negative relationship between the interest rate and inflation. This exercise also shows that prices have a long memory capable of impacting the interest rate and that the inflation rate is an indication for using IT as a policy instrument.

The SBP currently uses a backward-looking or adaptive form model to determine the path of the interest rate or inflation rate in the economy, while households and firms use rational expectations to indicate the path of inflation and stance of monetary policy in Pakistan. In this situation, IT could help stabilize the inflation-output relationship. There is no evidence for the accelerationist hypothesis in Pakistan. This means that we have a vertical type of Philips curve, which shows that policy behaviors are firm and not changing with respect to shocks in the economy.

The results confirm that the central bank has to pursue a more diversified objective while prioritizing the inflation rate via the interest rate. It needs to keep an eye on the output-inflation gap, exchange rate movements, and stability in the financial market. When a shock emerges in the economy, the nominal anchor moves to correct this disequilibrium, which results in loss of output and generates volatility in the system. These shocks are unpredictable and require a response from the central bank. This adds another dimension as to whether the policy response should be aggressive or conservative. The answer lies in the severity of shocks and uncertainty vis-a-vis the inflation-output tradeoff. If the inflation-output gap is volatile, then the central bank needs to adopt an aggressive stance. In this situation, IT would stabilize the inflation-output relationship.

We find that the interest rate channel exists for price stability in Pakistan. GDP growth and inflation during 1970-2009 are found to be negatively related, which makes the case for IT. We recommend that Pakistan should adopt flexible IT, which means that it can manage the exchange rate in addition to the interest rate, depending on the priorities emerging from inflation. To offset demand shocks in the economy, the SBP needs to win credibility by adopting aggressive monetary policy to monitor the future inflation rate. 
The choice of IT, with all its limitations, is a market-based mechanism. Properly functioning markets do not exist as a prerequisite. Pakistan's situation, however, demands IT as a commitment of the SBP. By exerting pressure on markets, this commitment will allow markets to grow and respond. The fiscal burden is an indicator of an underdeveloped financial market and the fragility of the financial market means that it is prone to more financial crises. The increased intensity of financial crises demands transparent financial policies and commitment to the public interest. Fiscal pressure is negatively associated with the choice of adopting IT. Tahir (2004) suggests financial sector reforms to improve the market mechanism and he stresses the need for a legal framework for adopting IT in Pakistan.

We conclude that IT per se is not an objective, but is a means to achieving the objective of transparent market-oriented polices and to stabilize growth by providing a level playing field for investors and savers. It is a policy with certain limitations and, like any other good policy, its benefits depend on the quality of commitment. 


\section{References}

Airaudo, M. (2004). Turkey Moves to Explicit Inflation Targeting? Some Lessons from a Simple Model of Policy Design With Imperfect Credibility. Paper presented at the LUISS Lab on European Economics, Rome, and Centre for European Policy Studies, Brussels.

Angeriz, A., and Arestis, P. (2005). Inflation Targeting: Assessing the Evidence. Cambridge: Centre for Economic and Public Policy, Department of Land Economy, University of Cambridge.

Ball, L., Mankiw, N.G., and Reis, R. (2003). Monetary Policy for Inattentive Economies. NBER Working Paper No. W9491.

Bank of Ghana. (2008). Annual Report 2007.

Bank of Ghana. (2001). Monetary and Exchange Rate Management.

Batini, N., and Haldane, A. (1999). Forward-Looking Rules for Monetary Policy. In John B. Taylor (ed.) Monetary Policy Rules. Chicago: Chicago University Press.

Bernanke, B.S., Laubach, T., Mishkin, F., and Posen, A. (1999). Inflation Targeting: Lessons from the International Experience. Princeton, N.J.: Princeton University Press.

Boughrara, A. (2004). Can Tunisia Move to Inflation Targeting? Developing Economies, 45 (1), 27-62.

Central Bank of Brazil. (2000). Issues in the Adoption of an Inflation Targeting Framework in Brazil. Research Department.

Czech National Bank. (2001). The Setting of the Inflation Target for 20022005. Retrieved from http://www.cnb.cz.

Ford, G. (1974). Whip inflation now. Retrieved from http:/ /en.wikipedia.org/wiki/Whip_Inflation_Now.

Gaiduch, V., and Hunt, B. (2000). Inflation Targeting under Potential Output Uncertainty. Reserve Bank of New Zealand Working Paper No. DP2000/08. 
Gottschalk, J., \& Moore, D. (2001). Implementing Inflation Targeting Regimes: The Case of Poland. Journal of Comparative Economics, 29 (1), 24-39.

Government of Pakistan. Pakistan Economic Survey. Various Issues. Islamabad: Finance Division.

Government of Pakistan. (2009). www.statpak.gov.pk/depts/index.htm, Federal Bureau of Statistics.

Greenspan, A. (1988). Testimony before the Committee on Banking, Finance and Urban Affairs, US Senate, July 13.

Hanson, M. S., and Nam, K. (2005). Inflation Targeting in an Emerging Market: The Case of Korea. Wesleyan Economics Working Papers, No. 2005-007.

Hebbel, K. S., and Tapia, M. (2003). Toward Floating and Inflation Targeting in Chile. Paper prepared for the CEPT/Deutsche Bank Research Workshop, Kronberg, Germany.

Hoffmaister, A.W. (2001). Inflation Targeting in Korea: An Empirical Exploration. IMF Staff Papers, 48 (2), 317-343.

$\mathrm{Hu}$, Y. (2003). Empirical Investigations of Inflation Targeting. IIE Working Papers Series, WP No. 03-6.

International Monetary Fund. (2007a). New Inflation-Targeting Countries. Monetary Bulletin, 2.

International Monetary Fund. (2007b). International Financial Statistics. [CD-ROM].

Kadioğlu, F., Özdemir, N., and Yilmaz, G. (2000). Inflation Targeting in Developing Countries. The Central Bank of the Republic of Turkey Discussion Paper.

Kim, S., and Park, Y. C. (2006). Inflation Targeting in Korea: A Model of Success? Department of Economics, Korea University, Seoul. BIS Paper No. 31. 
Kotlan, V., and Navratil, D. (2003). Inflation Targeting as a Stabilization Rule: Its Design and Performance in the Czech Republic. Czech Journal of Economics and Finance, 53, 220-242.

Malik, W.S., and Ahmed, A.M. (2010). Taylor Rule and Macroeconomic Performance in Pakistan. Pakistan Development Review, 49 (1), 37-56.

Masson, P., Savastano, M.A., and Sharma, S. (1997). The Scope for Inflation Targeting in Developing Countries. IMF Working Paper $97 / 130$.

McCallum, B.T., and Nelson, E. (1999). Nominal Income Targeting in an Open Economy Optimizing Model. Journal of Monetary Economics, 43 (3), 553-578.

McKinley, T. (2007). Why is Africa Constrained from Spending ODA? International Policy Centre for Inclusive Growth, Brasilia. One Pager No. 34.

Mishkin, F.S., and Posen, A.S. (1998). Inflation Targeting: Lessons from Four Countries. NBER Working Paper 6126.

Nenova, T., Niang, C., and Ahmad, A. (2009). Bringing Finance to Pakistan's Poor: A study on Access to Finance for the Undersaved and Small Enterprises. Washington, DC: The World Bank.

Opoku-Afari, M. (2008). Inflation Targeting a Turning Point in Ghana. Bank of Ghana.

Ozatay, F. (2004). High Public Debt, Multiple Equilibria and Inflation Targeting in Turkey. In Globalization and Monetary Policy in Emerging Markets. Bank of International Settlements Paper No. 23.

Saleem, N. (2008). Dynamics of Inflation, Exchange Rates and Inflation Targeting in Pakistan. Unpublished PhD Thesis, Government College University, Lahore.

Soderstorm, U. (1999). Should Central Bank be More Aggressive? Working Paper in Economics and Finance No. 309, Stockholm School of Economics.

Svensson, L.E.O., and Rudebusch, G.D. (1998). Policy rules for inflation targeting. NBER Conference on Monetary Policy Rules, 104, 125-145. 
Svensson, L. E. O. (2000). Open Economy Inflation Targeting. Journal of International Economics, 50, 155-83.

Svensson, L. E. O. (1999). Inflation Targeting as a Monetary Policy Rule. Journal of Monetary Economics, 43, 607-654.

Tahir, P. (2004). Institutional Arrangements for Financial Sector Governance. SBP Research Bulletin, 2 (1), 283-310.

Truman, E.M. (2005). Inflation Targeting in the World Economy. New Delhi: Viva Books.

World Bank. (2005). World Development Indicators. [CD-ROM]. 


\section{Appendix}

\section{Stability of the Model}
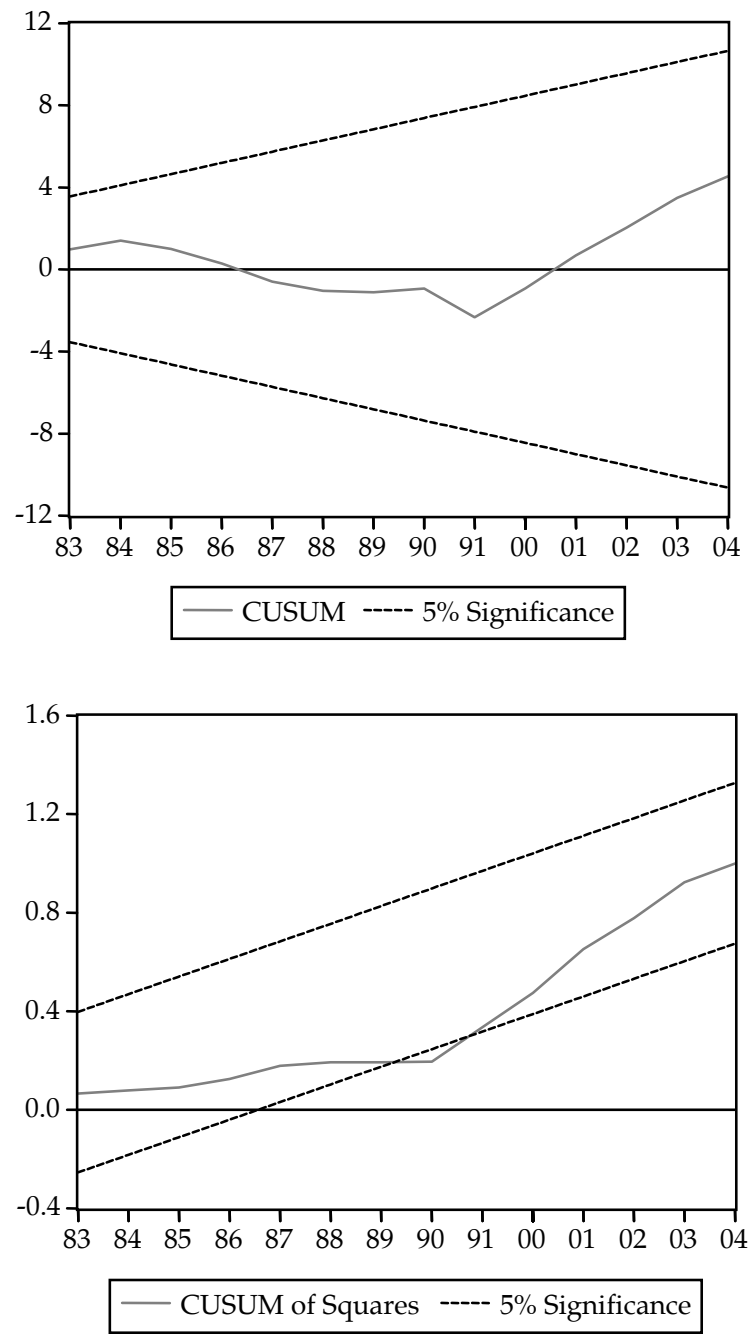